\title{
Territory and domestic ecology among the Kaiowa of Mato Grosso do Sul
}

\author{
Alexandra Barbosa da Silva' \\ Fabio Mura' \\ 'Programa de Pós-Graduação em Antropologia, Univerisade Federal da Paraíba, João Pessoa/PB, Brasil
}

\begin{abstract}
This paper aims to analyse the territorial dynamics resulting from the dissymmetric relationship between two processes of dominialisation in which the Kaiowa are involved in Mato Grosso do Sul. The first is represented by the process of territorialisation established by the creation of indigenous reservations and their management by the State, as well as the simultaneous and correlated formation of rural properties and urban centres. The second process, expresses the indigenous response to the territorialisation, through the ecology of their households, engendering adaptations in the activities of its members and strategies to regain control of their expropriated lands. Under these real conditions, the Kaiowa reflect on the configuration of their territorial spaces by creating important cultural categories related to them, thus revealing that territoriality is not an immanent and/or previously defined structure, but something that is historically constructed.
\end{abstract}

Keywords: Territorial Dynamics; Processes of Dominialisation; Processes of Territorialisation; Household Ecology; Kaiowa Indigenous. 


\section{Território e ecologia doméstica entre os Kaiowa de Mato Grosso do Sul}

\section{Resumo}

Este artigo busca analisar a dinâmica territorial decorrente da articulação dissimétrica de dois processos de dominialização que em Mato Grosso do Sul envolvem os Kaiowa. O primeiro é representado pelo processo de territorialização materializado na formação de reservas indígenas e na sua gestão por parte do Estado, bem como pela simultânea e correlacionada criação de propriedades rurais e centros urbanos. Já o segundo é expressão da resposta dos indígenas à territorialização, por meio da ecologia de seus grupos domésticos, dando vida a adaptações das atividades de seus membros, mas também a estratégias para recuperar o controle sobre seus territórios expropriados. A partir dessas condições concretas, os Kaiowa refletem sobre a configuração de seus espaços territoriais, produzindo importantes categorias culturais a eles relacionadas, revelando assim que a territorialidade é algo historicamente construído e não uma estrutura imanente e/ou previamente definida..

Palavras-chave: Dinâmica territorial; Processos de dominialização; Processo de territorialização; Ecologia doméstica; Indígenas Kaiowa. 


\title{
Territory and domestic ecology among the Kaiowa of Mato Grosso do Sul
}

\author{
Alexandra Barbosa da Silva \\ Fabio Mura
}

\section{Introduction}

In his classic essay on seasonal variations among the Eskimos, Mauss (1993 [1904-1905]) introduced the important category of social morphology, attempting to contrast the theories of the anthropogeographers of the time, which attributed a central power to soil characteristics in determining the shape of human settlements. Comparing Eskimos lifestyle and spatial mobility with other (indigenous) populations occupying the same regions, the French author showed how the Eskimos had developed a seasonal morphology, with the dispersion of households during the summer and their concentration in the winter, while the latter maintained constant mobility throughout the year. These adjustments greatly contributed to the development and use of different techniques and materials, appropriate to the social morphology adopted.

It should be noted, however, that if on the one hand, the analysis of social morphology leads us to overcome a certain kind of material determinism, on the other, in Mauss's terms, it hinders us from understanding how morphological variations are produced in the same ecological and territorial context. It also hinders us from understanding how individuals belonging to households, who engage in various activities and who relate to each other through exchanges, war, cooperation, competition, domination, etc., take advantage of these multiple experiences and how these condition their lives over time. Therefore, we cannot imagine that the mere study of the social morphology of a human group allows us to understand how it organises itself in space, since understanding how it interacts with other groups is also essential. The way in which these interactions occur is dependent on how resources are mobilised in these geographical spaces and ecological contexts are encountered, or to which they have been redirected, by diversified forces, both human and non-human. In these terms, as Barth observes

\begin{abstract}
"'Society' cannot be abstracted from the material context: all social acts are ecologically embedded. It is therefore not meaningful to separate "society" and "environment" and then show how the former affects or is adapted to the latter. Though the aggregate of social behaviours has a significant effect on the environment, and is contained within it, social decisions on all levels are connected with these ecological variables and have their forms significantly affected by them. Thus, the social and the ecological cannot, with respect the forms of social events and institutions, be treated as separate systems.” (1992: 20).
\end{abstract}

In order that the social and the ecological are not treated as separate systems, as the Norwegian author points out, we consider it opportune to embark on an effective surmounting of the distinction nature versus culture-society, seeking to bring together, under the same ontological horizon, aspects that are usually contrasted and not concatenated in the vital flow mobilised by distinct forces operating in the universe. These aspects configure socio-ecological-territorial contexts (Mura 2006, 2011), ${ }^{1}$ where the properties of the social that - as Barth points out, lead to diversity and variation (Barth 1987, 2005), defining modalities of access to information and resources - may be considered alongside other forces, physical or chemical,

\footnotetext{
1 With the notion socio-ecological-territorial context "we seek to understand how human and nonhuman elements, as subjects or objects, in a given place, relate to and interact with each other, forming sociotechnical systems and mobilising forces of the cosmos at their disposal” (Mura 2011: 114).
} 
which produce similar diversification effects in a given space of interactions and relations. It is important to consider that these socio-ecological-territorial contexts cannot be understood as atemporal, nor can the interactions and relationships that occur in them be seen as arising from a spontaneous action. They must be understood based on specific historical situations (Pacheco de Oliveira 1988), characterised by a peculiar mode of power distribution.

The very dichotomy between natural and supernatural, derived from that between nature and culture, should also be rethought. This theme has already been addressed elsewhere (Mura 2014), indicating how religion can be considered an organisational type, which is formed by producing boundaries between distinct dimensions, something that allows for the regulation of specific modalities of communication and the mobilisation of resources in the universe. Thus, while intergroup boundaries (domestic, ethnic, communal, national, etc.) allow for the construction of identities, defining relational symmetries and dissymmetries in the sensory world, religious relationships, through specialists (priests, shamans, mediums, etc.), analogously and simultaneously do the same between distinct dimensions. In both cases, the mobilisation of resource flows and the production of borders allows for the generation of spatial configurations, which may be bi, tri or multidimensional, depending on specific cases. It should be noted, however, that since we intend to focus predominantly on human actions and interactions, the point of reference of these configurations (where they come from) is generally the place that humans inhabit, i.e. geographical space. From this understanding, most cosmologies are found to be geocentric, with the level of access to the territory and its control determined by a human collectivity found to be crucial in the construction and administration of the relationships and interactions that its members establish in the universe as a whole.

Having control over a geographical space and seeking to control access to it and to the flow of materials (cultural and others) that circulate through it is central to the way individual and collective life is organised and how they inhabit the world. This tendency leads to the definition of domains that allow better organisation of access to and control of such flows, as well as establishing the knowledge and skills acquired through the experiential trajectories that the subjects gave life to, internally, within and beyond these spaces. Thus, processes directed towards the construction of domains in a given socio-ecologicalterritorial context will herein be referred to as processes of dominialisation (Mura 2017). ${ }^{2}$

Having said that, this article returns to the understanding of territorial dynamics that derive fundamentally from the dissymmetrical articulation of two types of dominialisation processes that affect the life of the Kaiowa in Mato Grosso do Sul. The first is represented by that which Pacheco de Oliveira (1998) defined as a process of territorialisation, meaning "an intervention from the political sphere that (prescriptively and unmistakably) associates a well-defined territory with a series of individuals and social groups" (1998: 56). In the specific case discussed here, territorialisation refers to the formation of indigenous reservations and their management by colonial and neo-colonial states, whereas the second type of dominialisation process is that promoted by the indigenous people, through the ecology of their households. ${ }^{3}$ Through the experiences of the members of these groups, this process is geared to exploring

\footnotetext{
2 On this, Mura affirmed: "If Foucault has made use of the pastoral metaphor to discuss governmentality among people, I consider it opportune to focus on the act of shepherding in the literal and technical sense, as a way of governing in the broader sense, relating human and non-human subjects, as well as forces and materials of different natures. The individualising action exerted by the man-shepherd corresponds to an attempt at governing, with significant implications in terms of the spatial configuration of the relationships in a certain socio-ecological-territorial context. This configuration, with implications in reactions, adaptations and mutual ties among all the subjects involved, manifests relationships of interdependence, in the manner indicated by Elias in understanding a social configuration (1991) - this concept is extended here to define what I call socio-ecological configuration. In turn, given that such a configuration is the result of domesticatory government practices, I define the actions that shape it as a process of dominialisation. I opt here for a neologism, in relation to the concept of domination, to highlight a dimension that besides being social, is also territorial and ecological. The aim is to show how each human or non-human subject tends to form domains, trying to impose, through direct or indirect actions, their will and power over other subjects or collectivities, as well as the material flows that they are concerned with" (Mura 2017: 30-31).

3 By households, here we mean units formed not only by co-residing inhabitants, but, as indicated by Wilk (1984, 1997) and Wallerstein (2004), a collective
} 
geographical spaces, enjoying the resources found there, and through the activities they develop, these members participate in the construction of a specific territory of reference.

The impact of the first type of process on the second has significant consequences, precisely on the construction of these territories. As we will see, the reduction of geographical spaces where Indians can settle, together with limitations of access to and use of other colonised spaces, lead to conditioning of the formation of the repertoires of possibilities (Mura 2000, 2011) of members of Kaiowa households - this is the relation between the accessibility and availability of desired resources. It should be observed, however, that here we are talking about a conditioning and not a determination. This is because, as Pacheco de Oliveira (1998) points out, processes of territorialisation are not one-sided, the Indians do not passively suffer their effects. Given the limitations of access to geographical spaces and their use, the Kaiowa react by engendering the adaptive and transformative processes of their domestic organisation, but also by establishing strategies and producing political movements to recover exclusivity of occupation and use of the territories traditionally occupied by them. In this process, they elaborate a complex cosmological vision and specific categories of territoriality.

To develop the idea proposed, the article is divided into three topics. The first is intended to provide a picture of the historical and cosmological processes in which the Kaiowa are the point of reference, observing their place in the world and their understanding of it, directly involving the colonial and neo-colonial relationships undertaken with non-Indians who have entered their territories. The second describes a domestic ecology, presenting composite calendars from which these Indians engender (and meet) a diverse range of techno-economic needs. Finally, an analysis of territorial dynamics seeks to address how the central categories of territoriality are produced by this people, combining their domestic activities with the process of retaking lands.

\section{Historical situations and the configuration of socio-ecological-territorial contexts}

At the time of the European conquest, the Guarani-speaking peoples occupied a vast geographical space, which included the present south and southeast regions, and significant parts of central western Brazil, eastern Paraguay, and northeast Argentina (Melià 1986; Susnik 1983). Colonial sources and archaeological studies describe the way of life of these Indians as centred mainly on agricultural activities, their populations distributed along rivers and at the headwaters of the same, forming local groups, which inhabited large huts. In exceptional cases, these huts could house a few hundred people, organised in extended families that distributed the conjugal families around the domestic fires present inside the constructions (MCA 1951; Susnik 1979-80, 1982; Mura 2006; Thomaz de Almeida 2001). Slash-and-burn agriculture was cultivated in the vicinity of these settlements, and a network of paths (tape po'i) extended from them, which led to more distant places, where they engaged in hunting and fishing activities. These paths also led to the settlements of other local groups, forming networks of kinship relationships and military alliances.

The territorial organisation described through the lens of missionaries and travellers over the centuries shows how these Indians live "dispersed" in space, rather than forming actual villages. ${ }^{4}$ The large huts,

united by a certain form of cooperation. From this understanding, as Wilk $(1984,1997)$ observes, many households can be organized as agglomerates of housing units linked together. These are usually extended families of three or more generations. The social organisation of work defines the logic of cooperation and the eventual differentiation of tasks performed by its members, which engenders a domestic ecology (Wilk 1997).

4 When the Jesuit Montoya defined, in 1639, what a reducción (mission town) was, where the Indians were moved, he indirectly ended up expressing precisely the way the Guarani occupied space. He expressed himself thus: "Note that we call them 'Reducciones' of 'peoples' or Indian settlements who, living in their former manner in jungles, mountains and valleys, by hidden streams, in three, four or six houses only, separated from each other by a distance of two or three leagues, or more, 'were reduced' under the diligence of the priests to not so small settlements and political (civilised) and human life, availed with cotton with which to dress, because they usually lived nude, not even covering what nature concealed.” (Montoya 1985 [1639]: 34; emphasis added). 
therefore, were not built in clusters, but were located, several kilometres apart with respect to one another, in ample territorial spaces between fluvial basins.

The effects of European colonisation on these peoples and their ways of inhabiting their territories are very significant. Specifically the Itatim, ancestors of the present Kaiowa, were partly reduced in Jesuit missions, and were later attacked by bandeirantes and by Mbaya-Guaikuru groups, as well as being afflicted by serious epidemics brought by the Europeans. As early as the middle of the seventeenth century, this population suffered a consistent demographic reduction, with contingents of people having to leave their spaces of origin, located in the region of what is now Bodoquena, on the edges of the Pantanal (Gadelha 1980). Thus, they settled in what is now the Southern Cone, in the State of Mato Grosso do Sul and in eastern Paraguay. In these spaces, compared with the dynamics of the spaces previously occupied by the Itatim (as indicated), until the middle of the nineteenth century the Kaiowa managed to develop a domestic ecology and construct their territories with relatively few colonial controls. Indeed, changes in the plans of the Portuguese metropolis, which redirected its interests of conquest and exploitation towards the State of Minas Gerais, together with the expulsion of the Jesuits from the Americas, with a consequent embargo and extinction of the experiences of the reducciones (mission towns), meant that the large geographical spaces where the Kaiowa had begun to reside were not subject to another physical occupation for over 100 years, with colonial investments limited to the experiences of explorers and missionaries (Thomaz de Almeida 1991, Barbosa \& Mura 2011).

In the second half of the nineteenth century, however, there was a significant change, largely as a result of the outcomes of the "Triple Alliance War" (1864-70), which led to a redefinition of the boundaries between Brazil and Paraguay. The spaces occupied by the Kaiowa were then divided by the new frontier, and impacted by an intense and systematic process of occupation and exploration of these places by two large tea companies: "Matte Larangeiras" and "Industrial Paraguaya". On the Brazilian side of the border, in a few decades, Matte Larangeiras began building railroads, highways, and river ports to ship the mate tea to the Platina region, and to bring materials and merchandise to the spaces it was exploring. It received concessions from the Brazilian State of more than five million hectares of land, most of these coinciding with the places occupied for centuries by the Kaiowa.

The systematic presence of the extractivist company led the Indians to engage intensely in tea production, through temporary jobs, known as changa (Melià et al. 1976). The intent was the possibility of access principally to fabrics, metal materials with which to make tools, salt and soap. This engagement led to a change in the Kaiowa way of inhabiting territories: the communal houses that housed extended families were gradually associated with other smaller buildings. This was mainly due to the strategies of extended families, which began to develop greater flexibility in their organisation, engendering a more diversified domestic ecology, systematically including the temporary work experiences of tea exploration. Thus, temporary shelters were built for conjugal families as these displacements advanced. Many interlocutors point out, however, that in most cases, these movements were not accompanied by the elderly, who tended to remain in certain parts of the territory, serving as a reference to their descendants. Hence, a more disperse form of territorial occupation came to life. On the other hand, new materials and subjects began to be contemplated, with which socio-technical relationships were established.

It was in this socio-ecological-territorial context that, between 1915 and 1928, the Indian Protection Service (SPI) created eight tiny reserves in the region to unite the Kaiowa and their Ñandéva neighbours, both of whom spoke Guarani. The perception of the indigenist organ was that both groups were dispersed, understanding (as the Jesuits had centuries before) that the Indians did not live in "proper villages". It was therefore be necessary to create them, through State intervention, to concentrate families considered to be "desaldeadas" [lit: unvillaged; having no village]. As Souza Lima (1995) points out, the aim was not only to settle 
indigenous people, but to simultaneously free land for colonisation - which, in fact, began to be developed, with the formation of farms, especially in the 1920s, when the Matte Larangeiras Company lost their exclusive right to exploit these wide geographical spaces. Thus, another important phase in the occupation of indigenous territories was inaugurated by neo-colonial fronts (Thomaz de Almeida 1991, Brand 1997).

The development of farms in the southern cone of what is now Mato Grosso do Sul was progressive, with different impacts on the indigenous communities located there. This was initially dominated by cattle raising, allowing most of the Kaiowa and the Nandéva to stay where they were. They came to be referred to as "[Indians from the] fringes of farms" (Thomaz de Almeida 1991, 2001), with farmers using their labour to establish and maintain their own farms. In the first few decades of the development of these rural "estates", the forests were still predominant, and the Indians continued to reside there. Relationships with the farmers were thus established in a piecemeal manner, through the activities of changa, which were necessary to attain materials and goods that they did not produce. The systematic and massive deforestation of the region - which took place between the 1960s and 1980s to implement intensive livestock and mechanised agriculture - led to the systematic expulsion of the Kaiowa and Ñandéva, who erected their local political communities in these spaces. Indigenous families were then massively removed by force or other forms of coercion to the reservations instituted decades before by the SPI. This gradual movement led to a population swell on the reserves, with families who were enemies and who came from different places being forced to reside side by side, provoking strong political tensions.

Thus, in the territories formerly used exclusively by the Kaiowa, cities, towns, and farms were formed, enclosed by walls, fences and porches, and a network of roads was created that currently occupies almost the entire region. Against this background, there was an indigenous reaction in the 1980 , with the retaking of lands they had traditionally occupied and the heightening of a struggle that lasts until today.

The historical facts briefly presented here allow us to identify distinct moments of indigenous life and its relationships and interactions with other peoples, for approximately 400 years 5 . These moments are characterised by the configurations of socio-ecological-territorial contexts in specific historical situations, diversified by several aspects, among the most significant of which is the access and control the Kaiowa have, to a greater or lesser extent, over the territories and the resources within them. The experiences of indigenous people in these contexts and situations, especially those marked by strong relationships of power due to the implementation of colonial and neo-colonial practices, allowed for the construction of a specific tradition of knowledge and cosmology. Interethnic relationships and the territorial dimension are revealed as key aspects to defining the architecture and dynamics of the cosmos, as understood by the Kaiowa. This cosmology, therefore, cannot be seen as something immanent or transcendent, but as a historical product (continuously under construction) and an integral part of the territorial dynamics in which the Indians participate.

In the next section, we will take a close look at the Kaiowa worldview and the answers they seek to provide to the problems they face, both from a practical and a moral point of view.

\section{Cosmological processes: in search of good living}

The Kaiowa seek to frame the problems they face in everyday life in a perspective constructed from a marked awareness of the movement of the universe, trying to condition it with their actions, in search of what is understood as tekovê porã (good living).

Their worldview is thus based on a continuous comparison between the "time-space of origins" (Áry Ypy), the present (Áry Ypyrã) and the process (already underway) of the end of the world (Ararapyre). The

5 For an in-depth study on the history of the Kaiowa, in addition to the texts already mentioned, see Monteiro 2003, Vietta 2007, Oliveira \& Pereira 2009, Cavalcante 2013, and Chamorro 2015. 
latter may be accelerated or decelerated, depending on the judgment of human behaviour on the part of the deities and/or by virtue of persuasion of the same by their shamans. Such collation between different space-times is directed towards constructing a moral and cognitive framework regarding the beings that populate the universe, emphasising their qualities at distinct moments. By presenting a perfect symmetry between the entities that inhabited the cosmos in the past, who all possessed shamanistic powers, spoke a single language and were immortal, the Kaiowa seek to show a process of decadence and hierarchisation of these living beings over time (Mura 2006). Through this comparison, they give meaning to the current architecture of the universe and how it came into being.

The separation of the pathways that communicated between the Earth (Yvy) and the celestial heights (yváy) produced the division of spaces between those now inhabited by pure beings, located beyond Yvy Rendy (the bright aura of the Earth) and the remainder located below that line where the imperfect beings reside. The subsequent concealment of these pathways also produced separation among diverse world dimensions: that where it is possible to perceive through common sensorial manifestations, and that where perception is possible only through hyper-senses, typical of shamanic abilities. Finally, cosmological conceptions are equally defined through collation between two equally cosmological spheres: that relating to the action and competence of the karai (non-Indian), and another concerning the Kaiowa, implying different ways of relating to the universe, which causes materials and energies circulating in them are channelled according to these divisions (Mura 2006, 2014).

According to the prestigious Kaiowa shaman Atanásio Teixeira, after a predominantly theogonic phase, led by Ñane Ramõi Jusu Papa (Our First Grandfather), the first Earth (Yvy Ypy) was created by the gods Verandyju and Yvakaju. At first, this Earth was a small disk a few centimetres in diameter, which would constitute the future centre of the current Earth (Yvy Pyrua ). Indeed, using the disc as the geographical point of departure, these deities enlarged it through ñengáry (prayers with strong shamanic power). Nane Ramõi completed the work, creating the forest, the waters and the mountains. Next, his son, Nande Ru Vusu (Our Great Father), formed a network of tracks (tape po'i) through his wanderings, which in turn, were used by Nande Sy (Our Mother), and by their sons Pa'i Kuara (owner of daylight) and by Jasy (owner of night light), children of Ñande Ru and grandchildren of Ñane Ramõi, to develop their actions on Earth in relation to the original humanities (Mura 2006).

Events of conflict between these humanities and their behaviours, considered inadequate by the deities, led Ñande Ru to destroy the surface of the first Earth and with it, the majority of its inhabitants. The renewed Earth was then repopulated with humanities devoid of original perfection and related to each other based on a hierarchy defined by a greater or lesser approximation with the gods. Thus, the majority of the beings we consider to be animals are understood by the Kaiowa as constituting humanities, though metamorphosis of an original anthropomorphism, who manifest the greatest degree of moral and behavioural decadence, and with whom it is possible to communicate only through prayers (ñembo'e). Regarding the other humanities, these are understood to form a network of kinship that refers, through genealogical ancestry, to the deities. The Kaiowa are related by direct bloodline to the main gods, understood as their own Ñande Rykey (Our Older Brothers). The other humanities originate from collateral lines, formed in the space-time of origins by affinity - understood, therefore, to be less close to the Nande Rykey compared with the Kaiowa (Mura 2006). In fact, the latter constitute the favourite people of the gods, on whom the fate of the earth depends.

This understanding also involves the realisation that everything in the universe has its owner (járy), such that the Earth, as the shaman Atanásio claims, is the exclusive property of the deity Chiru Kurusu Ñe'engatu (the Talking Cross of Chiru), who is Yvy Járy (owner of the Earth). The Earth is also held up by a large cross, 
made of chiru (a very powerful wood ${ }^{6}$ ), which is its support (jekoha). Other smaller crosses are distributed around her, to help keep her in equilibrium. With regard to the spaces on Earth's surface, these were ceded not as property, but as usufruct for humans, primarily for the Kaiowa, so that they could be put to good use. The feasibility of this was predicted in the time-space of origins by Nande $\mathrm{Ru}$, and the destination was given to extended (indigenous) families from specific places, close to the centre-navel of the Earth (Yvy Pyte). These families received chiru in the form of sticks and crosses so that, through these instruments, they could contribute to the equilibrium of the cosmos itself (Mura 2010). Thus, there is a set of supports, concatenated through the good behaviour of mutual support (teko mbojeko porã). We have Chiru Kurusu Ñe'engatu, the Earth and the extended Kaiowa families present in their places of origin as support for each other, and the tamõi (grandfathers) and jari (grandparents) as support for the households. In this aggregation, specific modalities of cosmological relationships are established that are fundamental to the search for cosmic balance, and with it, the quest to reduce the rhythm of the Ararapyre (end of the world), which, as we have seen, is a process that can be accelerated or decelerated depending on the situation.

Seeking cosmic balance is therefore an important task and simultaneously implies the search for good living (tekove porã), with the shamans interpreters of this state of life and evaluators of how to act to direct its course. It is evident to the Kaiowa that in order to achieve a satisfactory life, it is necessary to respect teko por $\tilde{a}$ (the correct way of being and living), and in this sense, the point of reference is the behaviour of the gods. Similarly, it is also relevant to compare past conditions with those of the present, which gives them the meaning of the effects of the domination suffered by the neo-colonial occupation of their territories. On the one hand, these comparisons allow them to cosmologically define the aforementioned division between cosmological spheres, assigning that under the dominion of whites, plastic, glass, metallic materials and objects of industrial origin, as well as the large-scale creation of domestic animals. On the other hand, this sphere does not prevent the passage of the elements under its competence to other spheres, it merely defines the limits of its use and reproduction. In these terms, the Kaiowa perceive that they are not qualified to reproduce the industrial objects and knowledge attributed to the sphere of competence of the whites; however, nothing prevents them from seeking to refine techniques and strategies to access them (see Mura 2006)'.

\section{Domestic ecology: morphological transformations, mobility and jeheka ("go in search of")}

As we have seen, the large indigenous huts, which during the period of the European conquest could house hundreds of people, progressively declined in size, and from the second half of the nineteenth century onwards, they were accompanied by other smaller constructions. During the 2oth century, such constructions became the majority and, since the 1970s, were the exclusive choice in terms of housing. It should be noted, however, that despite this significant change in housing construction, the organisation of local groups did not undergo radical changes (Mura 2000, Thomaz de Almeida 2001). In fact, whenever the opportunity presents itself, the contemporary Kaiowa seek to reproduce a pattern of non-nucleated spatial occupation, based on the spatial distance between the local groups, each formed by a te'yi (group based on kinship of at least three generations that can form, therefore, relatives on a broader basis). With the abandonment of the great huts, the same pattern began to be applied to the members of te'yi. Thus, whenever there are minimally favourable conditions, the extended family of three generations begins to form an aggregate household, which distributes the conjugal families that compose it into housing units

\footnotetext{
6 Myroxylon peruiferum, several varieties of a legume tree, known commonly in Brazil as "pau de bálsamo" [balsam wood].

7 For more in-depth study on cosmology and shamanism among the Kaiowa, see also Schaden 1974 [1954], Melià et al. 1976, Chamorro 1995, Pereira 2004 and Montardo 2009.
} 
(óy or oga) built in patios (oka) related to each other through of a network of paths (tape po'i) of hundreds of metres in length. The central axis of articulation is the oy of the oldest couple that is the origin of this group of relatives. This set of housing units, in turn, is connected through more extensive pathways (one or more kilometres in length) to similar sets, with whom they form a local community. Following this same proportionality, the spaces between related local groups are connected through even more extensive pathways, which can be up to a few tens of kilometres, forming local political communities through this alliance of relationships, known by the Kaiowa as tekoha. Finally, a broader network of trails across several tekoha defines what the indigenous people currently call tekoha guasu, a geographical space that is usually, but not necessarily, shaped by a river basin.

We will discuss the configurations of the tekoha and tekoha guasu in the next item. Before that however, we take a deeper look into how domestic ecology develops and how important it is both in the reproduction and adaptation of the social morphology, and in the spatial organisation of the Paî. ${ }^{8}$ They always seek to build their homes in places that guarantee drinking water and spaces suitable for agriculture. The smallholdings (kokue) are made around or in close proximity to housing units. Under favourable conditions, which are quite rare nowadays, cultivation is achieved by planting food crops among native vegetation, using techniques of slash-and-burn agriculture refined over centuries. Surrounding the kokue, traps are placed to capture animals that approach in search of the foods being grown there. The paths that go through these cultivars are designed not only for the residences, rather for the forest and fields nearby. People can also reach more distant locations, where they can engage in hunting activities - using bows and shotguns, fishing with nets, traps and choking techniques, or even collecting wild fruits and honey. The relationships with these spaces are sustained through technical operations that involve the use of prayers (ñembo'e), to convince several spirit-owners - like that of cultivated plants (Jakaira), the forest (Kurupyry), hunted animals (So'o Járy) and that of the waters (Kaja'a) - to grant access to these resources.

The domestic ecology developed by the Kaiowa follows a calendar that revolves around the agricultural activities, which also serve as reference for the main ritual activities. The cultivation of white maize (avati morotî), especially, allows them to perform avatikyry, the ceremony consecrating this corn and all new plants. It occurs during the harvest period between November and March of each year (see Melià et al., 1976, Chamorro 1995, Thomaz de Almeida 2001, Mura 2006). These periods are considered to be karu porã, that is, the abundance of food, with the off-season phases representing times of relative lack (karu vai). As indicated by Melià, Grünberg and Grünberg (Melià et al. 1976), in reference to Paraguay in the 197os, during the period of scarcity changa activities are intensified, and resources that compensate the meagre results of agriculture are sought in nearby farms. ${ }^{9}$ According to these authors, however, changa activities were then only complementary, with the resources coming from agriculture accounting for most of the intake, when the full annual cycle is considered.

It has been several decades since Melià et al. published their research, and if we look at the Brazilian side of the border, even in the 1970s the situation did not present itself as described for Paraguay. In fact, intense deforestation on the Brazilian side of the Kaiowa territory, as well as the systematic expulsion of the indigenous people from their places of origin, have created significant obstacles to the application of the slash-and-burn techniques adopted by these Indians. The African pastures (Brachiaria) introduced by ranchers and restrictions on the use of the spaces due to the implantation of farms, made the rotation of cultivable land, renovated through fire, difficult to achieve. This progressively led to the reduction in this form of food production, with the economic intake in other forms gradually acquiring more relevance.

\footnotetext{
8 "Paî-Tavyterã", or simply "Paî", is a form of self-denomination among the Kaiowa.

9 It is worth noting that the Kaiowa do not stock food in any quantity, even that derived from agriculture, and the accumulation of any kind of goods that are not distributed among close relatives is considered immoral and is heavily criticised.
} 
Another process that should be considered is what progressively transformed the households from units predominantly focused on production techniques - not only food, but also the objects and tools needed for the development of daily activities - to centres of the spread of acquisition activities. In fact, before the systematic relationship with whites, household equipment consisted of the acquisition of materials obtained mainly from the forest surrounding the homes, the constant increase in objects and metal, glass and plastic tools, as well as mechanical, electrical and electronic devices, led to a potentiation, expansion, diversification and refinement of acquisition techniques. The necessities of use by the households then demanded this transformation, from which rigid aggregates became flexible aggregates, as defined by Wilk (1984).'0

The domestic ecology thus began contemplating activities developed not only in forests, fields and rivers, but also in farms, cities, highways, places of garbage disposal. They then refine political techniques to capture so-called ethnodevelopment projects, and resources from municipal, state and federal governments. The members of the households can also engage as salaried workers (in indigenous schools and health units), enrol in benefit programmes, such as "Bolsa Familia", and, when elderly, receive rural retirement benefits. It is also possible for them to form seasonal labour flows in the alcohol production plants close by or in regions bordering their settlement sites.

Monetary resources from these activities and public policies have become increasingly significant for the domestic economy, with the calendar previously described becoming more complex. In effect, the annual cycle, based on the agricultural rhythm, articulates monthly cycles, due to a bureaucratic schedule that provides the aforementioned resources, and, more recently, a seasonal one, with work in the fuel alcohol plants, based on contracts that generally last 60 days. Finally, a final temporality (with weekly cyclicity) is added to those already described. It is represented by the work regime in the farms surrounding the indigenous lands or wherever the Indians are settled. This cyclicity establishes an alternation between working days in these rural properties and the weekend, dedicated to rest, such that this has two implications for the indigenous activities and the mobility that derive from them. On the one hand, the Kaiowa can periodically be on these farms, as temporary workers (involved in changa) and thus engaged in a pendular movement between the place of work and their domestic spaces. On the other hand, this difference between weekly work and rest periods means that on the weekends, on the farms, there is an absence of owners or managers and of the other employees - who go to urban centres in the region or even further. In these moments, the farm spaces become less controlled, allowing the Indians to enter, to hunt and collect fruits and medicinal plants, to fish, to collect thatch (for the roofs of houses), etc. Thus, the radius of action of these activities is never restricted to the small spaces that have been assigned to them by the State, since they seek to access and use, in various ways, all the spaces beyond where reside, which they consider as occupational, as they constitute the possible means of developing their lives, on their own terms and in their own ways.

In order to articulate all the activities and temporalities described, going from a production-based economic and technical organisation to one mainly centred on acquisition, the Kaiowa have refined what they call jeheka ("go in search of"). This word is composite of heka (pick up) and the particle jere (circulation). This concept thus highlights not the act of seeking something precise, known in advance, which would imply a linear trajectory - a fact that would be expressed by heka - rather what jeheka activities variously highlight is the act of circulating inside a territory, such that the resulting movement can be conditioned by many factors, due to conditions imposed by the interactions that occur during

10 The group living in a residence is called a dwelling unit, while a cluster of units under a single direction forms a household cluster. These groups, in turn, can be of two types: tight and loose (Wilk 1984: 224-227). In the first case, activities are linked more than anything to collective work, with all individuals in the household (depending on sex and age) performing similar tasks, especially those aimed at the production of food for self-consumption. In the second case, although their members continue to cooperate in some tasks and are focused on providing for the domestic unit as a whole, they can also develop differentiated activities, like engaging in wage labour, so that each housing unit can establish strategies of action with a certain autonomy. 
the course itself. The result of jeheka is thus partially planned, implying the making of distinct decisions in its composition. It would be inopportune, once an acquisition circuit is completed, to think of it as a predetermined or self-regulated system; the movement that gives it life effectively configures very open socio-technical systems, where the temporal factor is fundamental.

Although not based on pre-planned choices, the different temporalities and activities articulated by jeheka require, however, the refinement of a political behaviour that results from the practical experiences of household members. Such behaviour encounters moments of interpretation, synthesis and moral evaluation by the authority of the ñanderu (shamans) and the indigenous gerontocracy. This behaviour is based on and contributes to constructing criteria of relationships between Kaiowa subjects and the other subjects (human and non-human) with whom they engage, on Earth and in various levels of the universe. Thus, when people relate to the spirits who own the lands, forests, fields, and waters through jeheka, in some way they seek to mobilise resources, through strategies of persuasion, in order to take these to their homes. For example, when they relate to So'o Járy, it is so he will grant animals that are under his dominion, so they pass into the domain of the hunter. Briefly, the relationships of force and political interlocution between the two subjects of dialogue lead, in some way, to collate the processes of dominialisation of each of them, in this case, resulting in the momentary extension of the dominion of the second over that controlled by the first.

It should also be noted that when itineraries of jeheka reach cities, farms and commercial establishments (both urban and rural), indigenous behaviour bears a clear resemblance to those maintained in the environments described above. Regarding the relationship with the spirit-owners, this now involves that established with other similarly powerful beings: the karai (non-Indian). These, seen as dominators and with whom dialogue is difficult (because they seldom listen to the views of indigenous interlocutors) ${ }^{11}$, require that the Kaiowa approach with caution. In an inexorable coexistence, the intent is to establish an approximation that results in some form of advantage, in terms of resources or services. With the merchants and farmers, whom they call bosses, and with whom they also establish relationships of co-parenthood (Barbosa da Silva 2016), the Kaiowa seek bonds that produce in effect a reciprocity of obligations. In these terms and since they plan their actions to deal with short periods of time, they end up delegating to their non-Indian partners (especially the merchant bosses) the task of managing longer periods. Thus, through the excise of reciprocity, when necessary they ask favours to these bosses, using them as a kind of fund (a savings account), to be mobilised when circumstances require it, but without planning for it in advance.

However, it is possible to affirm that the displacements produced by jeheka practices allow activities to be linked in time and space, through individual and collective strategies, aimed at setting up composite calendars and itineraries (see Mura 2006). It should be emphasised that such practices are not totally decentralised, defining only an itinerant space, but neither are they the result of a solely radiant perception, from a centre towards its surroundings, according to arguments used by Leroi-Gourhan (1965) to distinguish and contrast the characteristics of territorial organisation of nomadic hunter and gatherer peoples, on the one hand, and sedentary farmers, on the other. The very mode of movement and use of space derived from the jeheka experience, through oguata (wandering) - which, as we have seen, encounters its cosmological sublimation in the time-space of origins, in the formation of tracks by the gods - occurs by strongly valuing centres of irradiation, with the Earth itself having developed from a disk, which later became the Earth's own navel. In this context, therefore, we speak of a modality of construction of territories from centres of wandering irradiation. In other words, the Kaiowa people construct spaces of

11 According to the aforementioned shaman Atanásio, this characteristic of not listening to the Kaiowa and of being greedy and selfish characterises the very mode of being of whites, the karai reko, which originates in the space-time of origins when the first white appears. For further study of this cosmological narrative, see Mura 2006; for the consequences of this behaviour in political terms and on social and political relationships with the Kaiowa, see Barbosa da Silva 2016. 
use and occupation through an "irradiated itineration". In fact, jeheka activities and those arising and/or correlated with them have an axis, that is, the point of departure and arrival, in the residential spaces of the various Kaiowa households.

In proceeding from an irradiated itineration in the daily development of jeheka two aspects are combined. ${ }^{12}$ On the one hand, an action aimed at socialisation and the production and transmission of knowledge (between individuals and generations) related to the territory, while, on the other hand, household members seek to assert their dominion over a given geographical space. It so happens that, with regard to the latter objective, they encounter limitations that have repercussions on the formation of the very repertoires of possibilities presented to them. In fact, the accessibility of resources depends not only on the availability of these items, but on the ecological and territorial configurations that present themselves at each moment in time, as well as other limiting effects, especially those imposed by the processes of dominialisation initiated by both non-Indians and by the actions and policies of the State. In the latter case, these occur through the attempts to contain the Kaiowa in villages within small spaces, freeing the remaining lands for the formation of private rural properties and urban centres. These effects translate into a hierarchical relationship of accessibility to and use of land by the Indians, in terms of the composition of exclusive and inclusive spaces of use and occupation, as well as the articulation achieved between them, through jeheka. This is one side, while on the other, these effects are also seen in terms of alliance and cooperation between various Kaiowa households, the formation of local political communities and the definition of broader territorial configurations - which engender a specific territorial dynamic, as discussed below.

\section{Territorial dynamics: neo-colonial conditioners and the notions of tekoha and tekoha guasu}

As we have seen, colonial sources refer to Guarani-speaking peoples as residing in large huts, forming a local group that housed a whole family group. Susnik $(1979-80,1982)$ refers to these spaces as constituting a te'yi-óga, thus emphasising the characteristic relationship between the extended family (te'yi) and the house (oga). The author also refers to the unit of guára, a territorial category broadly described in a Guarani language dictionary published by the Jesuit Montoya in 1639 (Montoya 1876). Guára, which linguistically means "coming from a certain place", when related to a river basin means revealing the distribution of the te'yi-óga according to the branches of rivers and tributaries. Based on these descriptions and definitions made in colonial sources, Susnik rightly considered guâra as the main unit of political-territorial articulation of the Indians in question, a unit based on egalitarian political relationships. However, during studies conducted in the 1970 s by Melià et al. among the Paî-Tavyterã (Kaiowa) in Paraguay, another category of territory was recorded that is now considered very significant, that of tekoha - from teko = "manner, way", and ha, a suffix that in this case indicates place, you have: "a place where we realise our way of being and living". It is through this category, as registered in contemporary ethnography, that Susnik indicates a presumed process of the centralisation of power among the Guarani, which had been defined in the period immediately preceding the European conquest, thus indicating an incipient though not widespread social hierarchisation. ${ }^{13}$

However, there are differences in the literature about whether the Guarani had constituted caciques. The archaeologist Soares (1997), for example, is of this opinion, which is based not on material findings,

\footnotetext{
12 It should be noted that displacements are also made for a variety of other motives (including witchcraft, fights, etc.) that influence the formation of local communities, a topic that will be discussed later.

13 "When several "te'yi" were associated, 5, 6 or more, they formed a local partner consciousness, a "villager" bond, "teko'a”. The Guarani, however, did not develop multi-population villages in the manner of the Chané-Arawak. At the beginning of the Spanish conquest, in some regions "teko'á" units were only recently in the process of integration, from which some socio-political peculiarities of 'guára' are derived” (Susnik 1983: 128).
} 
but on colonial sources, especially those related to the Jesuit missions pertaining to certain indigenous leaderships as tuvicha ruvicha ("the leaders of leaders") (cf. Susnik 1979-80). It should be noted, however, based on detailed tables elaborated by Wilde (2003) on the presence of the Indians in Jesuit reducciones, that the population related to each general cacique was relatively small, a few dozen people, representing a te'yi, thus referring to a local group or to several interrelated groups (Mura 2006). Melià is also of this opinion when he affirms that

"What the Spaniards of the time - the Jesuits among them - called cacicazgos, were often no more than "téyy", the meaning of which, according to the Treasure of the Guarani language by Montoya (Madrid 163gb: $f 376$ ), is "company, faction, genealogy, many". And these lineage factions did not have a fixed number of families. Those 400 families responding to 27 caciques, who gathered in San Pablo de Iniay, is an average of 15 families per cacique." (Melià 1986: 79-80).

Colonial sources are thus not authorised to speak of caciques or centralised forms of political organisation, integration and control of large population contingents, which are not described, except in eventual cases of large military or religious mobilisations, and generally in response to European colonisation (see Susnik 1979-8o, Melià 1986). Seeking, like Susnik, to understand the forms of organisation of the Guarani in the pre-colonial and colonial period, Melià uses the category of tekoha and states that

"The type of villages that the Jesuit sources describe show remarkable coincidences with the tekoha, as they are known through modern ethnography; hence deducing supposed analogies is permitted, even for those aspects that historical documentation does not designate" (1986: 104).

Unlike the Slovenian author, however, he does not identify a process of power centralisation in this territorial organisation. It is supported by the definition of tekoha itself, elaborated together with the Grünberg couple (Melià et al., 1976), in which this territorial unit was presented as "a community space of variable size, but with a constant structure and function, with religious leaders and its own policies". Each tekoha is autonomous with respect to others, thus there is no intercommunity political authority. In a typological definition, the authors add that the

"tekoha is usually an area well-defined by hills, streams or rivers and is exclusively communal property (tekohakuaaha), that is to say, the incorporation or presence of strangers is not allowed. Tekoha is a divine institution (tekoha ñe'e pyru jeguangypy) created by Ñande Ru" (Melià et al. 1976: 218 - emphasis added).

Well, it is a fact that today the Indians think about well-defined spaces, with fixed borders, circumscribing areas for the exclusive use of a community. However, it is necessary to analyse how such a concept came to be and what elements actually informed it. First, we have to ask whether it is an expression of an indigenous territoriality, independent of the historical conditions of its manifestation. As argued on other occasions (Thomaz de Almeida \& Mura 2004, Mura 2006, Barbosa \& Mura 2011), it is not appropriate to project the current characteristics with respect to such refined cultural categories to explain the territorial organisation in the colonial period and/or that preceded it. In fact, as Melià himself points out, the Jesuit sources are not exhaustive in this sense and when the author refers to the striking coincidences between what is described in contemporary ethnographies and what has been indicated by the Ignatics in the past, they are more concerned with certain characteristics of indigenous domestic ecology regarding the exploitation and techno-economic use of forests, fields and rivers - confirmed by archaeological data (Noelli 1993) - than with political and territorial aspects, such as the definition of physical and juridical frontiers, the exclusivity of use and occupation, or cosmological aspects, like the evaluative exaltation of the tekoha as an institution allocated by the deities. 
Regarding these last three aspects, colonial sources are not very rewarding, so much so that the previously mentioned Montoya dictionary is very rich when it comes to defining (over several pages) teko as "way of being and living", clarifying te' $y i$ as faction or lineage, and guára as a territorial category; but there is no record describing the relationship between teko and space as a politically organised territory. ${ }^{14}$ By this, we do not mean that this relationship did not occur. Indeed, sources in the Guarani language from 1752 and 1753, and recently made public (Neumann \& Boidin 2017: 118; www.langas.cnrs.fr) ${ }^{15}$ lead us to consider this relationship, though in a manner distinct to how the Kaiowa establish it nowadays.

These sources consist of letters elaborated by Indians in Jesuit missions shortly after the Treaty of Madrid (which apportioned the spaces of the Portuguese and Spanish colonies), endangering the occupation of the lands by the Guarani of the time. They felt threatened with expulsion, similar to the current context. It so happens, however, that in these letters the expression ore rekoha does not occur in isolation, but is always related to the term $y v y$ (earth), specifically "yvy ore rekoha".

Therefore, tekoha (in its oscillatory form rekoha), is not a noun, a concept in and of itself that indicates a political-territorial order as it is understood today, rather it expresses an action that occurs on earth $(y v y)$, with the latter being the main subject. In these sources, therefore, the expression " $y v y$ ore rekoha" meant either "the land where we (exclusively) are" or "the land where we (exclusively) live". This flexibility is due both to the multivocality of the term teko and the suffix "ha", which allows for several conceptual combinations. Moreover, the characteristics of the land in these sources can also be considered manifold, expressing the concept of being the actual flesh of the Indians ("ko yvy ore ro'o tee"), or a place that allows people to multiply as families ("ko yvy ore nemoñanga").

However, and this is of the utmost importance, when the sources speak of the land itself, no mention is made of either a territorial order or physical, fixed frontiers of units that divide it. This is not to say that no planning occurred, rather that we simply have no detailed knowledge of its characteristics. Thus, we feel that it is not fitting to force interpretations of colonial sources, acquired by their decontextualisation, to equate concepts and their contents to those currently promoted by the Indians. However, we do emphasise the relevance of these sources in providing a historical course of struggle engaged in by Guarani-speaking peoples regarding access to and control of their lands and the experiential consequences in the formulation of cultural categories that express territoriality. It is high likely that this secular experiential course underlies how the Kaiowa currently elaborate their territorial categories, particularly taking into account the last 150 years of history of interethnic contact, while subjected to processes of territorialisation that, as we have seen, have subtracted from spaces for the exclusive use of households where they settled. They have also largely lost those spaces that were inclusive, such as forests and fields, widely used in jeheka activities by a plurality of households, since only warlike hostilities placed transitional limits on this action.

Prior to the significant constraints imposed by neo-colonial activities of the Brazilian and Paraguayan States, social boundaries were not necessarily plottable in a given geographical space. This is due, in part, to genealogical movement, since after a few generations, through their descendants, local groups of the past can engender processes of splitting between the lineages of a te' $y i$. This phenomenon is frequent and, when there were favourable situations, it implied territorial distancing between these factions, with those less affluent seeking other places to settle their households, forming a new local group - which, over time, could lead to the formation of a new local political community. The relationships between close te'yi could change from a policy of alliance to one of enmity, engendering a sequence of territorial configurations.

\footnotetext{
14 The author briefly discusses the forms "tecóá" and "tecoá", the former meaning "imitation" and the latter "luck". The terms closest in meaning of spatiality are "tequába" and "teco hába", which respectively mean abode and divine stay (Montoya 1876). It should be noted, however, that they are closer in meaning to that currently attributed to tendápe than to the organisational and cosmological properties currently attributed to tekoha, which makes no mention of internal organisation and territorial boundaries.

15 We are grateful to Capidin Boidin for kindly providing information and reflections on these sources.
} 
Thus, limits in the scope of dominialisation of these extended families could change according to these configurational variations, as defined by Elias (1991).

Another fact is that the establishment of farms, with their fences and a regime of property based on Cartesian principles of spatial division, led to modification of the landscape, where fixed spatial boundaries began to be incorporated, conditioning indigenous mobility. Thus, you have a different territorial dynamic. ${ }^{16}$ It is precisely because of this impact that the Indians began to reflect on the limitations imposed on them by these policies of colonisation of their territories, leading them to assign boundaries to the spaces they occupied to try to defend them or to regain exclusive use of the places which they are conscious of originating from - places sublimated by the cosmological narratives and moralities expressed through teko pora (the correct way of being and living). It is thus, that we see the exaltation of a territorial unit that today is considered to be well defined, the exclusive right of a local political community: tekoha.

However, every te'yi considers itself to be from a certain place, referring to it as their tendápe - which, in this case, is the result of the relationship between a collectivity and a certain territorial space. Besides being of techno-economic order, this relationship is also defined through a territoriality that is constructed through the exaltation of geographical portions that acquire a particular meaning based on the memory of the collectivity that is linked to it. To this end, the experience and the memory of those who have resided there during a certain period and to whom it is possible to refer, through genealogical and cosmological ascension, is valued. ${ }^{17}$

These spaces acquire the characteristics of that which interested Bealet when proposing a "geography of the memory". Returning to the concepts of historians Nora and Martin of "place-memory" and "region-memory" respectively, ${ }^{18}$ the geographer Bealet (1997) started from the perspective that places "are the supports of a history, of a past. By their mere presence they allow you to remember." (: 324$)$. In the reconstruction of these memory-regions that are tendápe, the Kaiowa use toponyms often related to people who lived there, using the particle "kue" or "gue" ("that was"), which, associated with the names of people, indicate their previous presence in this location. Marks in space, such as rivers, streams, springs, trees, hills, etc., are also turned into toponyms, as are events occurring in a particular place, ${ }^{19}$ the existence of elements of fauna and flora, and the presence of invisible beings usually serve to denominate the territorial spaces of a tendápe. Just as Bensa (1996) indicates in the case the Kanak of New Caledonia ${ }^{20}$, these places form monuments that allow us to update and reinvigorate the memory of the past. This denomination is made through movement, the use and exploratory occupation of territories - through oguata, in ritual or jeheka activities, as well as through the constant visits to relatives located in distant settlements, by crossing spaces of old occupation (or, often, sneaking through them).

\footnotetext{
16 In an important pioneering paper on land use in Africa, Bohannan (1960) had previously highlighted the implications of the Cartesian division operated by the West and which had been imposed through colonial domination on native territories, altering access to land and its resources.

17 Thomaz de Almeida (2001) suggests using the concept (legal-political and administrative) of canton to refer to tendápe. Despite the sense of a jurisdiction over space in both cases, explicit clarification reveals the specificities of tendápe that have no equal in the concept of the Swiss State.

18 The study by J.C. Martin is entitled “La vendée de la mémoire”, 1989, Paris: Seuil; whereas that by Nora, is called “Les lieux de mémoire”. Paris: Galimard. 1984-1993 (3 tomes, 7 vols.).

19 For example, the place in the Sassoró reserve where the well-known tamõi (head of the te' yi) and ñanderu (shaman) Galiano (or Galino) lived is now referred to by many families (both inside and outside Sassoró) as "Galino Kuê". Similarly, "Jagua Amba Gue" is a place in the tekoha Kurusu Amba where a $\operatorname{dog}$ (in guarani, jagua 'i or jagua) died. It was on the edge of a stream, and its body fluids were mingling with water. Thus, this place became its last abode (emphasising that the word amba means the last place where a person or object rests) - v. Barbosa da Silva 2013.

20 "The routes memorise, from site to site, a migration that in fact reinforces the genealogical bond by uniting the members of the unit of relatives with their founding ancestor. The space - with its named places - which should be mapped - consigns a large family history that is always susceptible to extension by the last occupied dwellings. Around these "monuments", tangible remnants of the ancient presence of the ancestors and of men, the current identity of the group is reflected on and reconstructed - with a simple glance" (Bensa 1996: 3).
} 
The feelings generated by memory-regions are extremely strong, ${ }^{21}$ with the interruption of occupational continuity provoking the evocation and appreciation of the "ancient origin" (ymaguare). Thus, a sense of autochthony is refined that leads the Kaiowa to produce (when conditions permit) a circulation effect (Thomaz de Almeida 2001), with the Indians seeking to stay as close as possible to places where their ancestors lived, moving close to them, each time they are expelled or harassed.

When autonomous, the tendápe can be considered a tekoha, since this is a place where the Indians achieve their way of being and living. However, it is more common for the tekoha to be configured by the relationship between several te'yi, thus forming a territory that is the sum of a plurality of tendápe. In this sense, the territory of a tekoha is constituted by the exclusive spaces of the te'yi, conjugated with inclusive places (generally forests and fields) of common use. Since it is formed by the relationship between several tendápe, the tehoha constitutes a local political community, and its configuration, as we have seen, can vary according to alliances and enmities between the extended families involved. Therefore, contrary to the presumed rigidity, over time the extent and scope of a tekoha may vary. The size and scope of the lands claimed to be those traditionally occupied are based on memories of their occupation, those of Indians who are still living on them, or by their direct descendants (whether they lived there or not). However, the size and composition of their spaces depend not only on the configuration of the local political community at the time being considered, but principally by that formed by their descendants and current representatives. Thus, the te'yi that has most political power at the time of the claim can condition the composition of the spaces of the tendápe of origin, extolling the centrality of the one they originated from - in this case, its reference toponym tends to be extended, renaming the tekoha as a whole.

It is also important to highlight the impact that SPI and FUNAI policies have had on the size of the lands assigned to indigenous people over time. Indeed, the delimitations made since the 1970s in Paraguay and 1980 in Brazil have followed a much more rigid understanding of the definition of tekoha as areas with well-defined limits, to a large extent due to the effects of an experiment founded by the SPI model of territory, which, through an agrarian measure inherited from the colonial period, has assigned indigenous communities lots of one league in a block, that is 3,60o hectares. In many cases, these spaces were even negotiated with non-Indian squatters, thus further diminishing their size (Thomaz de Almeida 1991).

The decades-long experience of this state policy also served as a reference to indigenous peoples for their land claims until the 1980s. The practices of the indigenist negotiating body, as a way of supposedly expediting the demarcation of territories, was to restrict the size of these as much as possible. Thus, this model also guided the understanding that the Indians formed not so much about the size a tekoha would have as that which they could claim and defend before the State, by virtue of the socio-ecological-territorial context of the moment.

The dynamics that we have just discussed indicate that, in addition to the negotiations that the State eventually forces on them, with their movements the Kaiowa always attempt to dynamise territorial configurations over time. Indeed, this is because configurations of the tekoha derive from much wider geographical spaces, currently denominated tekoha guasu. The adjective "guasu", meaning "large" or "broad", shows that this territory is not the extension of a tekoha in size, nor the extension of the characteristics of its political organisation at an intercommunity level, rather "guasu" indicates that in this space, the way of being and living can be realised by a set of te'yi that, over time, has constructed its tendápe within the same.

21 Some reflections by Hirsch (1995) are important in this regard. Arguing about image and representation in the definition of the landscape by the human groups, the author establishes an important distinction between a Cartesian paradigm, which generates pre-established images of space, and Vichian, which links the perception of the same to feelings. 
The tekoha guasu have a certain analogy with the guára described in the colonial period, principally (but not always, nor exclusively) in its geographical references to river basins. ${ }^{22}$ In these regions, and not only in recognised or retaken indigenous lands, the Kaiowa circulate, using the spaces that compose it as they can and as dispersed as possible. In addition to settling on indigenous lands recognised by the State, households also settle on roadsides or (increasingly rarely) on farms, searching for places near water sources and the few forest areas that currently cover the southern cone of Mato Grosso do Sul. Several households, or parts thereof, have become bases in urban centres, and others are articulated as political communities, forming camps on lands they claim as their tekoha of origin. Thus, they form networks of relatives across different environments (Barbosa da Silva 2007, 2009), with movements (through oguata and jeheka activities) defining continuous explorations, experiences and appropriations of desired and accessible resources.

In these dynamics, as we have seen, indigenous people find significant obstacles to generating the domestic ecology they consider most appropriate. To these are added the effects of the struggle for land, which has recently led farmers to increase control of their properties, significantly hindering jeheka activities that take place there, in the tekoha guasu, further contracting the spaces held by indigenous people as inclusive.

Another factor that should be taken into account is the significant demographic growth of this people, which has not been accompanied by an appropriate distribution of the population in the spaces of the tekoha guasu. On the contrary, there is a very high concentration in tight spaces. Taking the tekoha guasu Iguatemipegua (see Map I) as an example, constituted by communities settled along the rivers that make up the fluvial basin of the Iguatemi River (over 400,0oo hectares), we encounter a population that was close to 10,000 individuals in 2014 concentrated on land effectively owned of approximately 10,000 hectares (indigenous lands plus camp spaces in retaken lands). The most emblematic case is the Takuapiry Indigenous Territory, established by the SPI in 1928, which has a population of 3,339 inhabitants on a mere 1,776 hectares. ${ }^{23}$ Therefore, the actual possession of exclusive use spaces in Iguatemipegua is less than $2.5 \%$ of the total area of the territory.

What we have witnessed over the past four decades is the tenacious commitment of political communities seeking to reverse this situation, recovering territorial spaces they were expelled from, in the process of territorialisation. By activating the notion of tekoha in the terms seen here, in a resolute movement, these communities have been reoccupying the tendápe where their te'yi originated, promoting occupations with each new violent expulsion on the part of farmers and paramilitary forces. ${ }^{24}$ They have suffered gunshot attacks, the murder and disappearance of several of their leaders, in the perpetration of a neo-colonial project that, in its attempts to put an end to these occupations, has ethnocidal and genocidal effects. As a peaceful but tenacious response to these practices, the "retomadas" [lit. retakings] $]^{25}$ are configured as a political action and project, the fruit of a collective reflection, aimed at the reconstruction of living conditions according to their teko (Benites 2014, Barbosa da Silva 2016).

22 For example, the tekoha guasu of the Iguatemi river basin, i.e. the "Iguatemipegua". The suffix "gua" (as in guára) means "coming from" - in this case, coming from this river basin.

23 The other two lands established by the SPI in 1928 also have significant populations: Sassoró with 2422 people on 1922 ha. and Limão Verde, with 1801 people on 668 ha. The other Indigenous Lands are: Jaguapire, with 1093 people on 2,349 ha; Takuaraty/Yvykuarusu, with 591 people on 2,609 ha. (both identified and delimited in the 1980s), and Arroyo Kora, with 606 people, in a camp situated within 7,175 hectares, delimited in the 2000 s. The sources considered here are SESAI, ISA and FUNAI.

24 These militias present themselves as private security companies. The most emblematic case is that of the Gaspem company, which was closed by determination of the Federal Courts, accused by the Public Prosecutor's Office of acting as a paramilitary force, while carrying out systematic attacks on indigenous communities. The documentary "Martírio" (Carelli et al., 2016), is dedicated specifically to land conflicts between the Kaiowa and has footage on this event, together with other footage filmed by the Indians themselves inside the camps, being shot at and intimidated by threats.

25 "Retomadas" are actions in which indigenous political communities in Brazil reoccupy parts of the land from which they were expelled or coerced to leave. In the Kaiowa case, this action is referred as "jaha jaike jevy" ("we're going in again"). These are areas traditionally used by their peoples, so they can reaffirm their community life: living according to their ways, establishing their dwellings, planting smallholdings, raising small animals, fishing, hunting, gathering, and practicing their ritual life. 
In this movement, the size of the retaken lands has grown steadily and significantly, also due in part to the effects of the Constitution of 1988. Recognising the right to the lands traditionally occupied, it defined more precise criteria to identify and delimit territories, including ecological factors, which are important to understanding the territorial dynamics. In the specific case of the Kaiowa and the Nandéva of Mato Grosso do Sul, these new conditions progressively led anthropologists and scholars of these indigenous peoples to reflect on how the delimitations of the tekoha were achieved.a result, in 2007, the FUNAI redefined the methodology previously used to meet indigenous claims, signing a Commitment for Adjustment of Conduct (CAC) together with the indigenous peoples and the Public Prosecutor's Office. The FUNAI placed six technical groups in the field to develop studies on the territorial demands located in hydrographic basins or other spaces that academic research indicated as forming the tekoha guasu. This procedure resulted in the delimitation not only of larger areas of land (something that has already been verified from 1995 onwards), but several indigenous lands were no longer circumscribed by the tekoha, but as portions of tekoha guasu, in which a plurality of tekoha of origin were contemplated and where the Kaiowa and Ñandéva were able to configure and reconfigure, with greater territorial flexibility, the relationship between the tendápe and the communities that articulate them. ${ }^{26}$

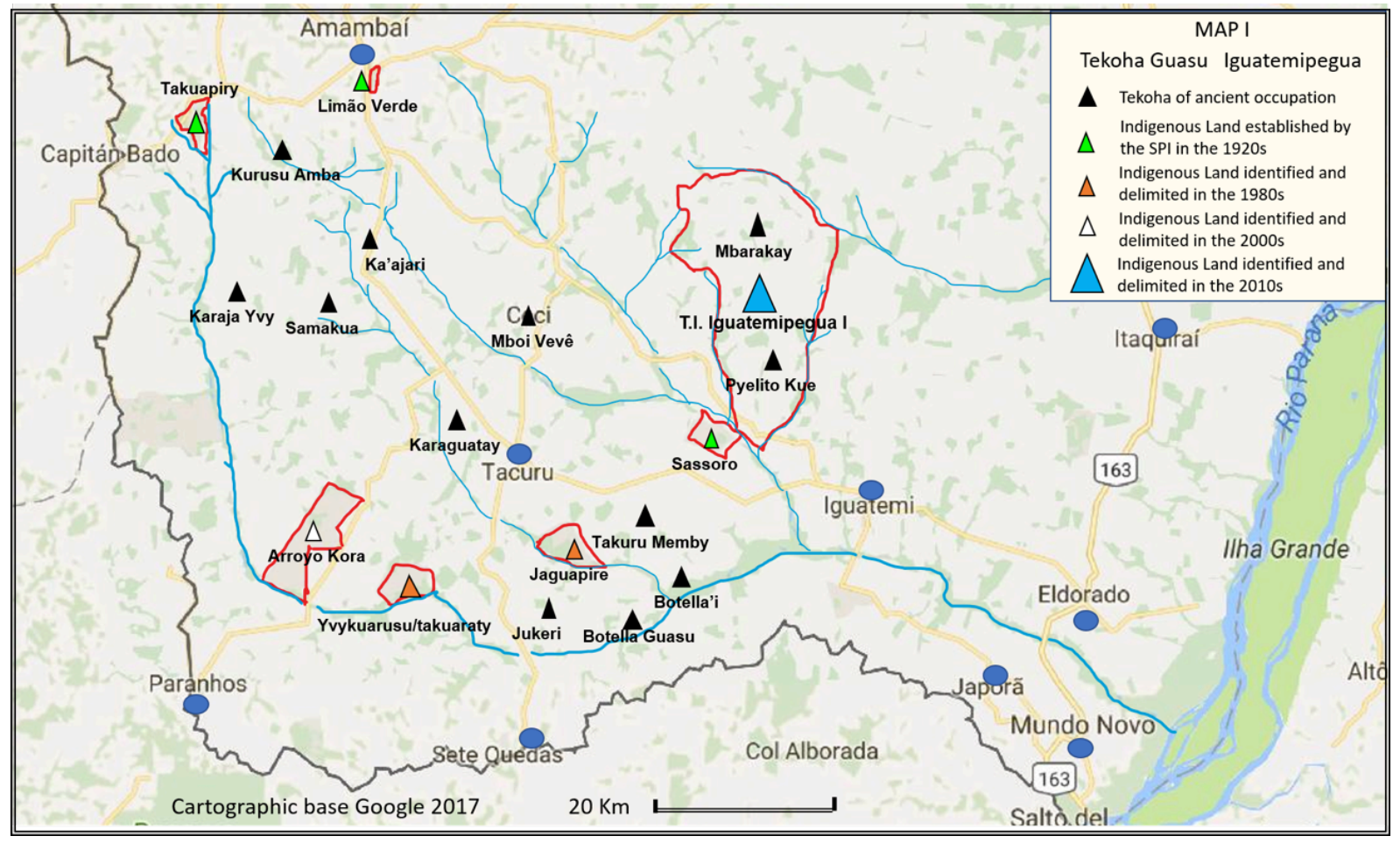

The effects of this methodology and the resulting work have encountered (and continue to encounter) significant obstacles, due to the resistance of rural producers who feel their particular interests are affected. In order to defend them, as far as possible, they have sought treat the processes of indigenous land regularisation judicially, while also influencing or pressuring numerous instances of government to paralyse or significantly reduce the pace of land regularisation. Therefore, from the identifications and delimitations from the six technical groups, so far only three lands have been published in the Federal Official Gazette, two of them referring to the Kaiowa, and which precisely follow the criterion of being part of tekoha guasu. The first was the Iguatemipegua Indigenous Territory I (see Maps I and II), of 41,571 hectares, and the second was Dourados-Amambaipegua Indigenous Territory I (see Map II), 55,600

26 For a detailed description of the CAC, the operational plan of the FUNAI and the activities of the six technical groups, see Cavalcante 2013. 
hectares. These were the result of two separate technical groups, each of which contemplated two other indigenous lands (Iguatemipegua II and III, and Dourados-Amambaipegua II and III, respectively), which ten years after the CAC, FUNAI has not yet published, very similar to other indigenous lands identified by the remaining technical groups.

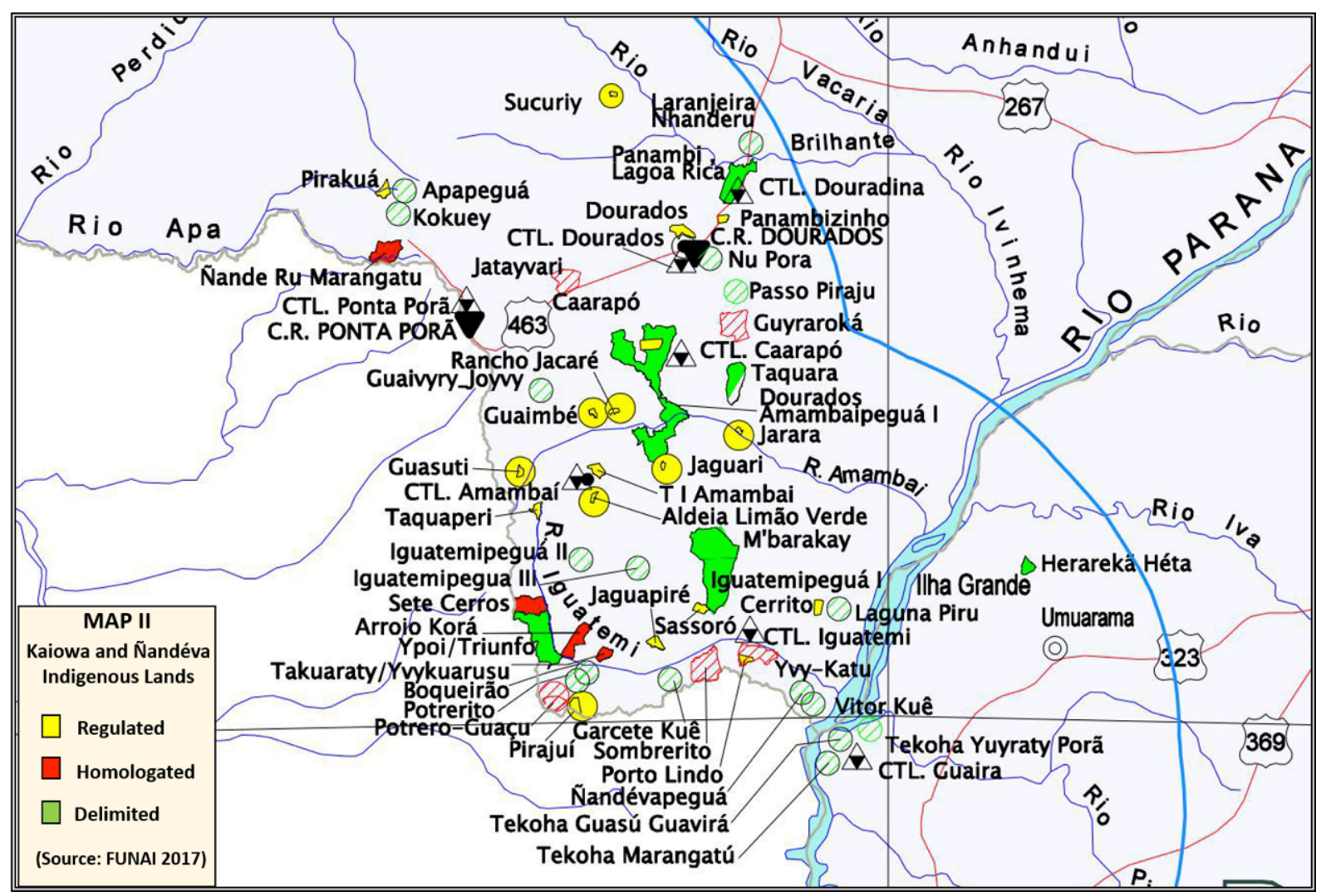

\section{Final considerations}

In light of what we have seen and argued concerning the territorial dynamics and processes of dominialisation involving the Kaiowa, in conclusion we want to highlight two aspects for reflection on the construction of territories and territorialities, reaffirming certain theoretical considerations presented in the introduction. One is the importance of the adaptive and transformative processes of the activities of indigenous households over time in response to the characteristics of the socioecological-territorial contexts encountered in each moment and that they contribute to configuring. This shows that the territoriality and territories cannot be considered as mere reflections of the social morphology of the group, considered without reference to the historical situations in which they are manifested and refined.

A second and no less important aspect is that the transformations of cultural activities, institutions and concepts can follow distinct rhythms and intensities, depending on their emotional and affective relevance to the subjects. Often times, certain aspects of daily life tend to change rapidly to allow the reproduction of others, which are considered to be unrenounceable or even inevitable. Thus, as we have seen, while the Kaiowa transform and refine domestic ecology in a given context, they seek to guarantee and enhance the morphological characteristics of mobility and the modalities of spatial occupation defined over hundreds of years of practical experience. These characteristics are very important to the Kaiowa who, through them, seek to contrast the extremely negative effects of an enucleated spatial organisation, constantly and intensely imposed on them, through systematic territorial expropriation 
and, later, in the restriction of access to their spaces of traditional occupation, which, as we have argued, is perpetrated much of the time by the Brazilian State itself.

To conclude, in light of that discussed herein, it should be emphasised that despite unveiling neocolonial power and violence contrary to indigenous territorial rights, the Kaiowa have not given up on recovering their tekoha. This is predicated on the conviction that its attainment alone guarantees the realisation of their way of being and of living (teko), and consequently the maintenance of the equilibrium of the Earth, making good use of it. This use is not merely an option for them, rather it represents a duty, imposed by the deities themselves, who chose this people as their favourite, destining them to live and care for the centre of the Earth, precisely where their territories are.

Received: November 11, 2017

Approved: June 11, 2018

Translated by: Phil Badiz 


\section{References}

BARBOSA, Pablo A.; MURA, Fabio. 2011. "Construindo e reconstruindo territórios guarani. Dinâmica territorial na fronteira entre Brasil e Paraguai (sec. XIX e XX)”. Journal de la Société des Américanistes, 97-2: 287-318.

BARBOSA DA SILVA, Alexandra. 2007. Mais além da "aldeia": território e redes sociais entre os Guarani de Mato Grosso do Sul. Tese de doutorado. PPGAS-MUSEU NACIONAL/Universidade Federal do Rio de Janeiro. . 2009. "Entre a aldeia, a fazenda e a cidade: ocupação e uso do território entre os Guarani de Mato Grosso do Sul”. Tellus, 9(16): 81-104. . 2013. "Relatório circunstanciado de identificação e delimitação da Terra Indígena Iguatemipegua I". Brasilia: FUNAI. Mimeo. . 2016. "Processos identitários e relações patrão-cliente entre os Kaiowa". Mana. Estudos de Antropologia Social, 22(1): 37-66.

BARTH, Fredrik. 1987. Cosmologies in the Making. A Generative Approach to Cultural Variation in Inner New Guinea. Cambridge: Cambridge University Press.

. 1992. "Towards greater naturalism in conceptualizing society". In: Adam Kuper (ed.), Conceptualizing society. London: Routledge. pp. 17-33.

. 2005. "Etnicidade e o conceito de cultura". Antropolítica, 19: 15-30.

BEALET, M. 1997. "Religion et Région Mémoire: Esquisse d'une territorialité par la biais de la Géographie de la Mémoire”. Norois, Revue Géographique de I'Ouest et des Pays de I’Atlantique Nord, 44(174): 317-329.

BENITES, Tonico. 2014. Rojeroky hina ha roike jevy tekohape (Rezando e lutando): o movimento histórico dos Aty Guasu dos. Ava Kaiowa e dos Ava Guarani pela recuperação de seus tekoha. Tese de doutorado. PPGASMUSEU NACIONAL/Universidade Federal do Rio de Janeiro.

BENSA, Alban.1996. "La memoria de los lugares entre los Kanaks de Nueva Caledonia ('La Gran Tierra'), Nueva Caledonia". Universidad de Ciencias y Artes del Estado de Chiapas (UNICACH). pp. 26-33. Mimeo. BOHANNAN, Paul. 1960. “Africa's land”. The Centennial Review of Arts \& Science, 4(4): 439-449.

BRAND, Antônio. 1997. O impacto da perda da terra obre a tradição Kaiowá/Guarani: os difíceis caminhos da palavra. Tese de doutorado, Programa de Pós-Graduação em História, PUC/RS.

CARELLI, Vincent; CARVALHO, Ernesto \& ALMEIDA, Tatiana. 2016. Martírio: a insurgência pacífica e obstinada dos povos Guarani Kaiowa. Brasil: Papo Amarelo Produções Cinematográficas Ltda - ME.

CAVALCANTE, Thiago L. V. 2013. Colonialismo, território e territorialidade: a luta pela terra dos Guarani e kaiowa em Mato Grosso do Sul. Tese de doutorado. Faculdade de Ciências e Letras de Assis-UNESP.

CHAMORRO, Graciela. 1995. Kurusu Ñe'ëngatu. Palabras que la historia no podría olvidar. Biblioteca Paraguaya de Antropología, vol. 25. Asunción: Centro de Estudios Antropológicos.

. 2015. História Kaiowa: das origens aos desafios contemporâneos. São Berdardo do Campo: Nhanduti Editora.

ELIAS, Norbert. 1991. Qu' est-ce que la sociologie. Paris: Éditions de l'Aube.

GADELHA, Regina M. A. F. 1980. As missões jesuíticas do Itatim: um estudo das estruturas sócio-econômicas coloniais do Paraguai (séc. XVI e XVII). Rio de Janeiro: Paz e Terra.

HIRSCH, Eric. 1995. “Landscape: Between Place and Space”. In: Hirsch \& O’ Hanlon (eds.), Landscape: Perspective on Place and Space. Oxford: Clarendon Press. pp. 1-30.

LEROI-GOURHAN, André. 1965. Le geste et la parole II: La mémoire et les rythmes. Paris: Albin Michel. MANUSCRITO DA COLEÇÃO DE ANGELIS (MCA) - 1951. Jesuítas e Bandeirantes no Guairá. Vol. I. Rio de Janeiro: Biblioteca Nacional, Divisão de Obras Raras e Publicações.

MAUSS, Marcel. 1993 [1904-1905]. "Essai sur les variations saisonnières des sociétés eskimos. Étude de morphologie sociale”. In: Sociologie et Anthropologie. Paris: Quadrige / PUF. 5르. ed. pp. 389-477. 
MELIÀ, Bartomeu. 1986. El Guarani conquistado y reducido: Ensayos de etnohistoria, vol.5. Asunción: Biblioteca Paraguaya de Antropología.

.; GRÜNBERG, Friedl \& GRÜNBERG, Georg. 1976. “Los Paî-Tavyterã: Etnografia guarani del Paraguai contemporaneo". Suplemento Antropológico de la Revista del Ateneo Paraguayo, XI(1-2): 151-295.

MONTARDO, Deise Lucy O. 2009. Através do mbaraka: música, dança e xamanismo guaraní. São Paulo: Edusp. MONTEIRO, Maria Elisabete Brea. 2003. Levantamento histórico sobre os índios Guarani Kaiwá. Rio de Janeiro:

Museu do Índio/ Funai. Coleção Fragmentos da História do Indigenismo, 2.

MONTOYA, Antonio Ruiz de. 1876 [1639]. Tesoro de la Lengua Guarani. Leipzig: B.G. Teubner. . 1985 [1639]. Conquista espiritual feita pelos religiosos da Companhia de Jesus nas províncias do Paraguai, Paraná, Uruguai e Tape. Porto Alegre: Martins Livreiro Editor.

MURA, Fabio. 2000. Habitações Kaiowa: forma, propriedades técnicas e organização social. Dissertação de mestrado. PPGAS-MUSEU NACIONAL/Universidade Federal do Rio de Janeiro. . 2006. À procura do "bom viver": território, tradição de conhecimento e ecologia doméstica entre os Kaiowa. Tese de doutorado. PPGAS/MUSEU NACIONAL/ Universidade Federal do Rio de Janeiro. . 2010. "A trajetória dos Chiru na construção da tradição de conhecimento Kaiowa". Mana. Estudos de Antropologia Social, 16(1): 123-150. . 2011. "De sujeitos e objetos: um ensaio crítico de Antropologia da técnica e da tecnologia". Horizontes Antropológicos, 17(36): 95-125.

. 2014. "Beyond nature and the supernatural: Some reflections on religion, ethnicity and traditions of knowledge". Vibrant, 11(2): 407-441. . 2017. Dinâmica territorial, ecologia doméstica e processos sociotécnicos: um estudo comparativo a partir de casos entre os Kaiowa de Mato Grosso do Sul e os Tabajara da Paraíba. Projeto de pesquisa para pós-doutoramento. DCS-CCAE-UFPB. Mimeo.

NEUMANN, Eduardo S.; BOIDIN, Capucine. 2017. "A escrita política e o pensamento dos Guarani em tempos de autogoverno (c. 1753)". Revista Brasileira de História, 37(75): 97-118.

NOELLI, Francisco Silva. 1993. Sem tekoha não há tekó. Em busca de um modelo etnoarqueológico da aldeia e da subsistência guarani e sua aplicação a uma área de domínio no delta do Rio Jacuí - RS. Dissertação de Mestrado, Programa de Pós Graduação em História/ PUC-RS.

OLIVEIRA, Jorge E.; PEREIRA, Levi M. 2009. Ñande Ru Marangatu. Laudo antropológico e histórico sobre uma terra kaiowa na fronteira do Brasil com o Paraguai, município de Antônio João, Mato Grosso do Sul. Dourados: Editora UFGD.

PACHECO DE OLIVEIRA, João. 1988. O Nosso Governo: Os Ticuna e o regime tutelar. São Paulo: Marco Zero/ Brasília: MCT-CNPq. . 1998. "Uma etnologia dos 'índios misturados'? Situação colonial, territorialização e fluxos culturais". Mana. Estudos de Antropologia Social, 4(1): 47-77.

PEREIRA, Levi M. 2004. Imagens Kaiowa do sistema social e seu entorno. Tese de Doutorado. Programa de PósGraduação em Antropologia Social-Universidade de São Paulo.

SCHADEN, Egon. 1974 [1954]. Aspectos fundamentais da cultura guarani. São Paulo: E.P.U. / EDUSP. SOARES, André Luís. 1997. Guarani. Organização social e Arqueologia. Porto Alegre: EDIPUC-RS. SOUZA LIMA, Antônio Carlos de. 1995. Um grande cerco de paz: poder tutelar, indianidade e formação de Estado no Brasil. Petrópolis: Vozes.

SUSNIK, Branislava. 1979-80. Los Aborígenes del Paraguay, vol. II - Etnohistoria de los Guaraníes: época colonial. Asunción: Museo Etnográfico Andrés Barbero. . 1982. Los Aborígenes del Paraguay, vol. IV - Cultura material. Asunción: Museo Etnográfico Andrés Barbero. 
. 1983. Los Aborígenes del Paraguay, vol. V-Ciclo vital y estructura social. Asunción: Museo Etnográfico Andrés Barbero.

THOMAZ DE ALMEIDA, Rubem F. 1991. O projeto Kaiowa-Ñandeva: uma experiência de etnodesenvolvimento junto aos Guarani-Kaiowa e Guarani-Ñandeva contemporâneos do Mato Grosso do Sul. Dissertação de Mestrado. PPGAS/Museu Nacional / UFRJ.

. 2001. Do desenvolvimento comunitário à ação política: o projeto Kaiowa-Ñandeva como experiência antropológica. Rio de Janeiro: Contra Capa Livraria.

. \& MURA, Fabio. 2004. "Historia y territorio entre los Guarani de Mato Grosso do Sul, Brasil”. Revista de Indias, LXIV(230): 55-66.

VIETTA, Katya. 2007. Histórias sobre terras e xamãs kaiowa. Territorialidade e organização social na perspectiva dos Kaiowa de Panambizinho. Tese de doutorado. PPGAS- Faculdade de Filosofia, Letras e Ciências Humanas - USP.

WALLERSTEIN, Immanuel. 2004. World-System analysis: An Introduction. Durham and London: Duke University Press.

WILDE, Guillermo. 2003. Antropología histórica del liderazgo guaraní missionero (1750-1850). Tese de doutorado. Facultad de Filosofia y Letras. Universidad de Buenos Aires.

WILK, Richard. 1997. Household ecology: Economic change and domestic life among the Kekchi Maya in Belize. DeKalb: Northern Illinois University Press. . 1984. "Households in process: agricultural change and domestic transformation among the Kekchi Maya of Belize". In: R. McC. Netting; R. R. Wilk; E. J. Arnold (eds.), Households. Comparative and historical studies of the domestic group. Berkeley: University of California Press. pp. 217-244.

.; NETTING, Robert McC. 1984. "Households: Changing Forms and Functions". In: R. McC. Netting; R. R. Wilk; E. J. Arnold (eds.), Households. Comparative and Historical Studies of the Domestic Group. Berkeley: University of California Press. pp. 1-28.

WILK, Richard et al. 1984. “Introduction”. In: R. McC. Netting; R. R. Wilk; E. J. Arnold (eds.), Households. Comparative and Historical Studies of the Domestic Group. Berkeley: University of California Press. pp. xiii-xxxviii.

\section{Alexandra Barbosa da Silva \\ PPGA / Federal University of Paraíba \\ Contact: alexandrabaro1@gmail.com}

Fabio Mura

PPGA / Federal University of Paraíba

Contact: fabiomura64@gmail.com 